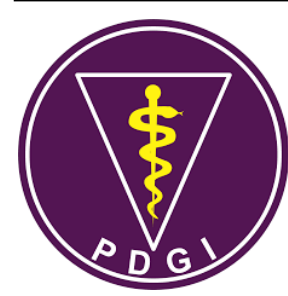

\title{
Influence of Two Root Canal \\ Obturation Techniques with Resin Based Sealer to Enterococcus faecalis Penetration
}

\author{
Aryadi Subrata ${ }^{1 \S}$, Anastasia Elsa Prahasti ${ }^{1}$, Bernard Ongki Iskandar ${ }^{1}$ \\ ${ }^{1}$ Department of Conservative Dentistry, Faculty of Dentistry, Trisakti University, Indonesia
}

Received date: January 19, 2019. Accepted date: March 1, 2019. Published date: April 30, 2019.

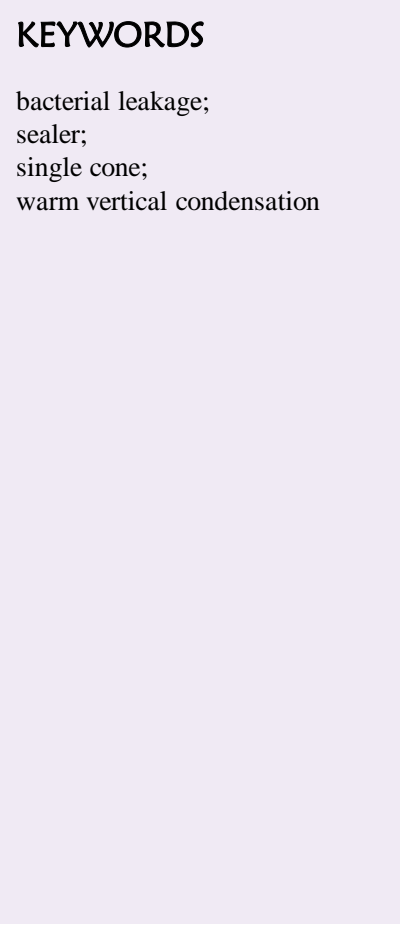

\begin{abstract}
Introduction: Root canal treatment is done to maintain the teeth to last as long as possible in the oral cavity. This can be done with three main stages, such as biomechanical preparation, sterilization and root canal filling. The hermetic seal of root canal filling has an important role in the success of root canal treatment. Objective: The aim of this in-vitro study is to compare the microbial leakage of root canals filled with RealSeal sealer/Resilon Points and AH Plus sealer/conventional gutta-percha points using single cone obturation technique and warm vertical compaction technique. Methods: Thirty-two extracted human mandibular premolars with single canals were decoronated to a standardized root length of $15 \mathrm{~mm}$ and prepared using crown-down technique to a master apical file size 30/.09. Teeth were divided into four experimental groups ( $n=7$ each group) and controls $(n=1$ each group). Teeth in the first group were obturated using single master gutta percha cone and AH Plus sealer and second group were obturated with single Resilon gutta percha cone using RealSeal sealer. Third experimental group was filled with warm vertical condensed gutta-percha using AH Plus sealer and fourth group was filled with warm vertical condensed Resilon gutta-percha using RealSeal sealer. The coronal chamber of each sample were inoculated with Enterococcus faecalis. Results: There were no significant differences between the four experimental groups $(\mathrm{P}=$ 0.182). The differences occurred only in the survival time from each group. Group 4 (Warm Vertical Condensation - RealSeal) has the lowest leakage rate among other groups and the fastest leakage occurred in group 1 (Single Cone - AH Plus). Conclusion: The single-cone techniques does not insure durable apical seal against bacterial leakage. Warm vertical compaction technique using Resilon gutta-percha and RealSeal sealer appears to be more effective in minimizing bacterial leakage than gutta-percha and AH Plus sealer.
\end{abstract}




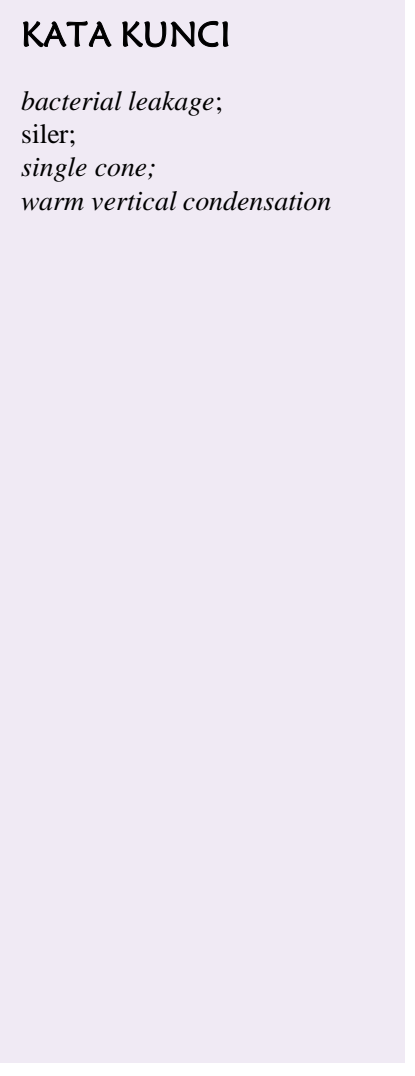

\begin{abstract}
ABSTRAK
Pendahuluan: Perawatan saluran akar dilakukan untuk mempertahankan gigi agar dapat bertahan selama mungkin dalam rongga mulut dengan tiga tahap utama yaitu preparasi biomekanis, sterilisasi dan pengisian saluran akar. Pengisian saluran akar yang dilakukan dengan kedap memiliki peranan yang penting terhadap keberhasilan perawatan saluran akar. Tujuan: Untuk menentukan dan membandingkan kebocoran bakteri pengisian saluran akar dengan siler RealSeal dengan guta perca Resilon dan siler AH Plus dengan guta perca konvensional menggunakan teknik pengisian single cone dan teknik warm vertical condensation. Metode: Subyek penelitian adalah 32 gigi premolar bawah dengan saluran akar tunggal, gigi dipotong bagian korona sampai dengan panjang sampel $15 \mathrm{~mm}$, seluruh saluran akar dipreparasi menggunakan teknik crown down sampai dengan ukuran 30/.09 . Seluruh sampel penelitian dibagi menjadi 4 kelompok secara acak ( $n=7$ untuk setiap kelompok) dan kontrol ( $n=1$ untuk setiap kelompok). Kelompok I diobturasi dengan siler AH Plus dan guta perca konvensional menggunakan teknik single cone. Kelompok II diobturasi dengan siler RealSeal dan guta perca Resilon menggunakan teknik single cone. Kelompok III diobturasi dengan siler AH Plus dan guta perca konvensional menggunakan teknik warm vertical condensation. Kelompok IV diobturasi dengan siler RealSeal dan guta perca Resilon menggunakan teknik warm vertical condensation. Seluruh sampel kecuali kontrol diinokulasi dengan bakteri E. Faecalis pada bagian korona. Hari terjadinya kebocoran dicatat untuk evaluasi. Hasil: Tidak ada perbedaan kebocoran bakteri secara signifikan antar kelompok. Perbedaan yang terjadi hanya "survival time" dari masing-masing kelompok. Kelompok IV (Warm Vertical Condensation - RealSeal) memiliki kebocoran terendah dari kelompok lain. Kebocoran tercepat terjadi pada kelompok I (Single Cone - AH Plus). Kesimpulan: Teknik single cone tidak menjamin penutupan apikal yang baik dari kebocoran bakteri. Pengisian dengan teknik warm vertical condensation menggunakan siler RealSeal dan guta perca Resilon menunjukkan hasil yang lebih baik dalam mengurangi kebocoran bakteri daripada pengisian dengan menggunakan siler AH Plus dan guta perca konvensional.
\end{abstract}

\section{PENDAHULUAN}

Perawatan saluran akar merupakan salah satu jenis perawatan yang bertujuan mempertahankan gigi tetap berfungsi. Keberhasilan perawatan saluran akar dapat dicapai bila memenuhi kriteria trias endodontik, yang meliputi akses pembukaan, pembersihan dan pembentukan, serta pengisian saluran akar. ${ }^{1}$ Tujuan utama perawatan saluran akar yaitu menghilangkan sumber infeksi bakteri dan mengisi saluran akar dengan baik secara tiga dimensi. Kombinasi guta perca dan siler adalah bahan pengisi saluran akar yang paling sering digunakan dalam praktek dokter gigi. ${ }^{2}$

Fungsi siler adalah mengisi ruangan antara guta perca dan dinding saluran akar serta bagian-bagian yang sulit terisi atau tidak teratur. ${ }^{3}$ Siler berbahan dasar resin yang sering dipakai dan telah digunakan bertahun-tahun serta menunjukkan keberhasilan klinis, antara lain siler AH Plus dan siler Epiphany. Siler AH plus dapat digunakan menggunakan guta perca biasa sedangkan siler Epiphany biasanya digunakan bersamaan dengan guta perca khusus yang bernama Resilon dan membentuk suatu ikatan yang disebut monoblok. ${ }^{4}$ Saat ini, siler Epiphany sudah berganti nama menjadi siler RealSeal. ${ }^{5}$

Banyak teknik yang dikembangkan untuk mengisi saluran akar antara lain teknik single cone, teknik lateral kondensasi, ${ }^{6}$ dan warm vertical condensation. ${ }^{7}$ Berbagai macam teknik pengisian saluran akar menunjukkan derajat kebocoran yang berbeda-beda, perbedaan ini berdasarkan adaptasi bahan dengan dinding saluran akar dan penetrasi bahan ke dalam saluran akar lateral dan tubuli dentin. ${ }^{8}$

Mengevaluasi kualitas pengisian saluran akar sebagai tahap terakhir dari perawatan saluran akar merupakan hal yang penting dilakukan. Banyak metode tes yang dikembangkan untuk mengevaluasi kemampuan penutupan bahan pengisi saluran akar yang antara lain, penetrasi pewarnaan, radioaktif isotop, bakteri atau kebocoran metabolit bakteri, dan cairan filtrasi. ${ }^{9}$ Menurut Torabinejad dkk., ${ }^{10}$ penetrasi bakteri lebih bermakna dan relevan secara klinis dalam penelitian kebocoran dibandingkan dengan penetrasi zat pewarnaan. Salah satu bakteri yang paling persisten yang ditemukan di dalam saluran akar pada gigi yang sakit setelah perawatan saluran akar adalah bakteri E. faecalis. Bakteri ini ditemukan hampir di $90 \%$ kasus kegagalan perawatan saluran akar. ${ }^{11}$

Saluran akar yang sudah terlindungi dapat terkontaminasi kembali apabila terjadi penundaan tumpatan restorasi permanen yang cukup lama. Ketika situasi ini terjadi, bagian koronal sistem saluran akar akan terkena mikro-organisme. Pertanyaannya adalah seberapa cepat sistem saluran akar akan terinfeksi bakteri lagi. ${ }^{10}$ 
Sampai saat ini belum diperoleh informasi adanya penelitian yang sesuai dengan studi yang akan dilakukan.

\section{BAHAN DAN METODE}

Seluruh sampel penelitian sebanyak 40 sampel gigi premolar bawah dengan saluran akar tunggal yang telah dikumpulkan dilakukan pengambilan foto Röntgen untuk memastikan bahwa gigi hanya memiliki satu saluran akar dengan derajat kurvatura akar lurus. Dari 40 sampel yang telah disiapkan, dipilih 32 sampel secara acak kemudian semua sampel gigi disimpan di dalam larutan salin. Seluruh sampel penelitian disamakan panjangnya dengan dipotong menggunakan wheel diamond bur sampai panjang sampel $15 \mathrm{~mm}$. Saluran akar dipreparasi dengan teknik crown down menggunakan Protaper Rotary 21 $\mathrm{mm}$, preparasi saluran akar dimulai dengan menggunakan file S1 sampai dengan F3 (30/.09) sesuai panjang kerja. Preparasi dilakukan dengan bantuan EDTA 15\% (RCPrep). Setiap pergantian jarum dilakukan irigasi dengan larutan sodium hipoklorit $(\mathrm{NaOCl}) 2,5 \%$ sebanyak $5 \mathrm{ml}$. Irigasi terakhir secara berurutan sebelum dilakukan pengisian yaitu dengan $\mathrm{NaOCl} 2,5 \%$, EDTA $17 \%$, akuades, klorheksidin 2\% (Cavity Cleanser, Bisco).

Sampel secara acak dikelompokkan ke dalam 4 kelompok: kelompok perlakuan I, kelompok perlakuan II, kelompok perlakuan III, dan kelompok perlakuan IV, masing masing kelompok terdiri dari 8 sampel dengan 1 sampel sebagai kontrol. Kelompok I dilakukan pengisian dengan teknik single cone dengan guta perca dan siler AH Plus. Kelompok II dilakukan pengisian dengan teknik single cone dengan guta perca Resilon dan siler RealSeal. Kelompok III dilakukan pengisian dengan teknik warm vertical condensation dengan guta perca dan siler $A H$ Plus. Kelompok IV dilakukan pengisian dengan teknik warm vertical condensation dengan guta perca Resilon dan siler RealSeal. Pengisian saluran akar dikonfirmasi menggunakan foto rontgen untuk melihat hasil pengisiannya lalu sampel disimpan dalam kelembaban selama 72 jam.

Tabung Eppendorf plastik dipotong bagian bawahnya sehingga bagian apikal dari sampel penelitian dapat keluar menonjol dari tabung Eppendorf. Sampel penelitian dengan saluran akar yang sudah terisi dimasukkan ke dalam tabung Eppendorf sampai bagian apikal sampel keluar dari tabung. Lem epoxy dilekatkan di perbatasan antara tabung Eppendorf dengan bagian apikal sampel yang keluar dari tabung untuk menutup celah yang terdapat diantara sampel dengan tabung Eppendorf sehingga tidak terjadi kebocoran. (Gambar 1) Tabung Eppendorf yang sudah disiapkan diletakkan di 30 $\mathrm{mL}$ tabung gelas yang berisi $10 \mathrm{~mL}$ steril phenol yellow broth dengan 3\% laktosa dengan apeks akar tercelup sedalam $5 \mathrm{~mm}$ dalam broth. Tabung gelas disterilisasi lalu diinkubasi pada suhu $37^{\circ} \mathrm{C}$ selama 3 hari. (Gambar 2)

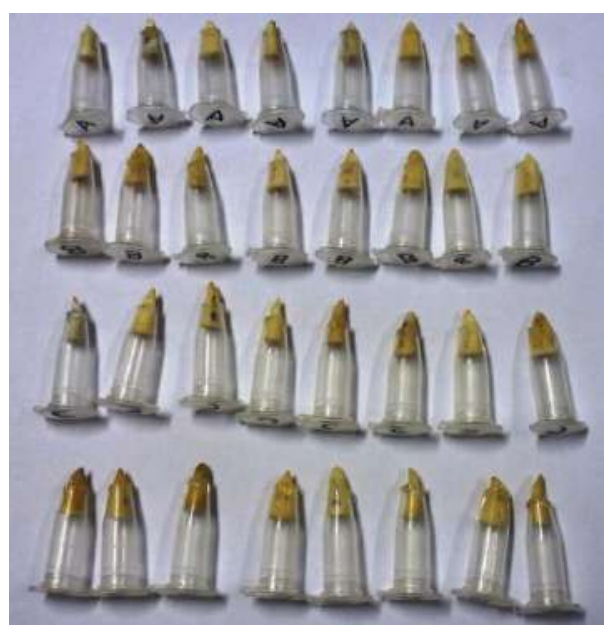

Gambar 1. Sampel penelitian yang sudah dilakukan pengisian saluran akar dimasukkan ke tabung mikro.

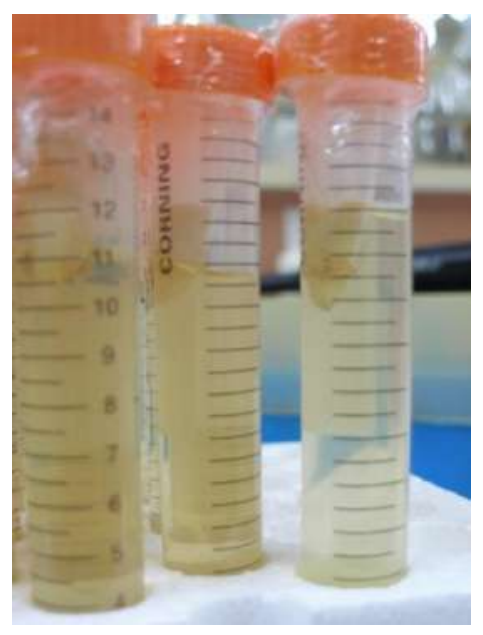

Gambar 2. Sampel penelitian dipindahkan ke dalam tabung reaksi $15 \mathrm{~mL}$ yang sudah berisi phenol yellow broth.

Setiap kelompok diinokulasi dengan $0,5 \mathrm{~mL}$ Enterococcus faecalis (E. faecalis) yang mengandung $3 \times 10^{8}$ Colony Forming Unit (CFU)/mL pada bagian coronal chamber. Sampel kontrol di setiap kelompok tidak diinokulasi bakteri. Media yang berisi mikroorganisme diganti setiap 3 hari. Selama masa penelitian, perubahan warna kuning pada broth menjadi merah yang mengindikasikan bahwa bakteri sudah mencapai apikal diperiksa dan dicatat setiap hari untuk evaluasi. Pengamatan dilakukan selama 60 hari

Data yang diperoleh dianalisis secara non parametrik dengan menggunakan uji statistik Kruskal-Wallis untuk mengetahui perbedaan pengaruh dua teknik pengisian saluran akar menggunakan dua siler berbahan dasar resin terhadap penetrasi E. faecalis dan uji statistik KaplanMeier untuk mengetahui survival time dari penetrasi $E$. faecalis. 


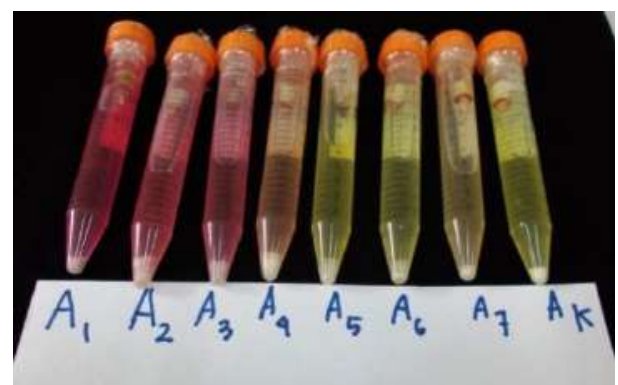

Gambar 3. Perubahan warna terjadi pada tabung A1-A3 yang menandakan sudah terjadi kebocoran pada pengisian saluran akar

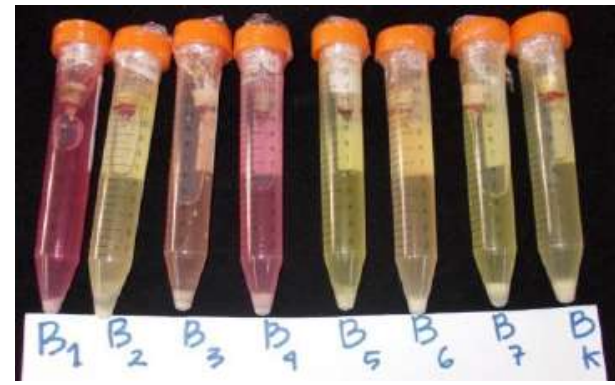

Gambar 4. Perubahan warna terjadi pada tabung B1, B3, B4 yang menandakan sudah terjadi kebocoran pada pengisian saluran akar

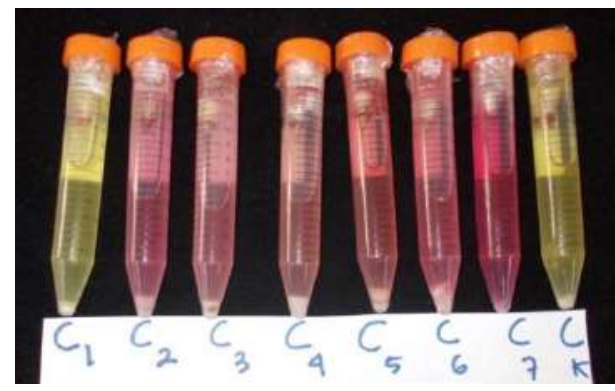

Gambar 5. Perubahan warna terjadi pada tabung $\mathrm{C} 2-\mathrm{C} 7$ yang menandakan sudah terjadi kebocoran pada pengisian saluran akar

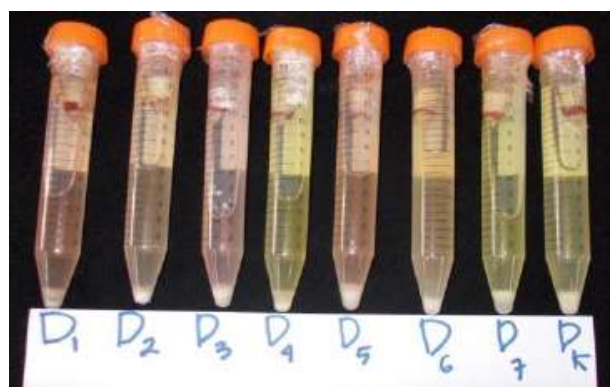

Gambar 6. Perubahan warna monor terjadi pada tabung D1-D3, D5-6 yang menandakan sudah terjadi kebocoran pada pengisian saluran akar
HASIL

Perubahan media lactose broth dapat dilihat dengan perubahan warna yang terjadi dari warna kuning menjadi merah dengan bantuan pengamat di laboratorium Pusat Penelitian Ilmu Pengetahuan dan Teknologi (Puspiptek, Serpong). Subjek kontrol menunjukkan tidak adanya perubahan warna pada media lactose broth. Dalam penelitian ini ditemukan data bahwa kombinasi warm vertical condensation - RealSeal menunjukkan skor terendah atau paling kedap dari mikroorganisme $E$. faecalis dengan mean-rank 10,57 diikuti single cone RealSeal dan single cone - AH Plus masing-masing 13,0 dan 14,86 sedangkan mean-rank tertinggi adalah kombinasi warm vertical condensation - AH Plus dengan mean-rank 19,57 (Tabel 1). Selanjutnya, data diuji perbedaan dengan menggunakan uji statistik KruskalWallis untuk menguji perbedaan antar kelompok. Ternyata hasil uji tersebut menyatakan tidak terdapat perbedaan yang bermakna diantara kelompok-kelompok tersebut (Nilai $\mathrm{p}=0,182$; Tabel 2).

Pada hasil uji statistik Kruskal-Wallis tidak terdapat perbedaan bermakna antara kelompok-kelompok, akan tetapi pada penelitian ini tetap ada perbedaan dalam hal kelangsungan hidupnya, oleh karena itu dilakukan uji statistik Kaplan-Meier. Hasil uji statistik Kaplan-Meier (Tabel.3) yaitu pada kelompok 1 (Single Cone - AH Plus) memiliki kebocoran tercepat, penetrasi bakteri yang terjadi pada hari ke-35 memiliki persentase kebocoran 71,4\%. Pada kelompok 2 (Single Cone - RealSeal), penetrasi bakteri yang terjadi pada hari ke-51 memiliki persentase kebocoran 57,1\%. Pada kelompok 3 (Warm Vertical Condensation - AH Plus), penetrasi bakteri yang terjadi pada hari ke-35 memiliki persentase kebocoran $71,4 \%$. Pada kelompok 4 (Warm Vertical Condensation RealSeal) memiliki tingkat kebocoran yang paling rendah diantara kelompok yang lain, penetrasi bakteri yang terjadi pada hari ke-57 memiliki persentase kebocoran $85,7 \%$.

Tabel 1. Hasil rata-rata kebocoran yang terjadi pada kelompok Single Cone - AH Plus, Single Cone RealSeal, Warm Vertical Condensation - AH Plus dan Warm Vertical Condensation - RealSeal

\begin{tabular}{lcc}
\hline \multicolumn{1}{c}{ Kelompok } & N & $\begin{array}{c}\text { Rata- } \\
\text { rata }\end{array}$ \\
\hline Single Cone - AH Plus & 7 & 14.86 \\
$\begin{array}{l}\text { Single Core - RealSeal } \\
\text { Warm Vertical Condensation }\end{array}$ & 7 & 13.00 \\
- AH Plus & 7 & 19.57 \\
$\begin{array}{l}\text { Warm Vertical Condensation } \\
- \text { RealSeal }\end{array}$ & 7 & 10.57 \\
\hline
\end{tabular}


Tabel 2. Hasil Uji Kruskal-Wallis

\begin{tabular}{ll}
\hline & Skor \\
\hline Chi-Square & 4.862 \\
Df & 3 \\
Nilai P & 0.182 \\
\hline
\end{tabular}

Tabel 3. Hasil uji Kaplan-Meier mengenai waktu dan persentase terjadi kebocoran antar kelompok.

\begin{tabular}{|c|c|c|c|c|c|c|c|}
\hline \multicolumn{2}{|l|}{ Kelompok } & \multirow{2}{*}{$\begin{array}{l}\text { Waktu } \\
35.000\end{array}$} & \multirow{2}{*}{$\begin{array}{l}\text { Status } \\
\text { Bocor }\end{array}$} & \multicolumn{2}{|c|}{$\begin{array}{c}\text { Cumulative } \\
\text { Proportion } \\
\text { Aurviving at the } \\
\text { Time }\end{array}$} & \multirow{2}{*}{$\begin{array}{c}\begin{array}{c}N \text { of } \\
\text { Cumulative } \\
\text { Events }\end{array} \\
1\end{array}$} & \multirow{2}{*}{$\begin{array}{c}\begin{array}{c}\text { Nof } \\
\text { Remaining } \\
\text { Cases }\end{array} \\
6\end{array}$} \\
\hline Single Cone $-A H$ & 1 & & & & & & \\
\hline & 2 & 35.000 & Bocor & 0.714 & 0.171 & 2 & 5 \\
\hline & 3 & 57.000 & Bocor & 0.571 & 0.187 & 3 & 4 \\
\hline & 4 & 67.000 & Bocor & 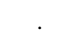 & . & 4 & 3 \\
\hline & 5 & 67.000 & Bocor & 0.286 & 0.171 & 5 & 2 \\
\hline & 6 & $67.00+$ & $\begin{array}{l}\text { Tidak } \\
\text { Bocor }\end{array}$ & $\cdot$ & . & 5 & 1 \\
\hline & 7 & $67.00+$ & $\begin{array}{l}\text { Tidak } \\
\text { Bocor }\end{array}$ & - & . & 5 & 0 \\
\hline \multirow{7}{*}{$\begin{array}{l}\text { Single Core - } \\
\text { RealSeal }\end{array}$} & 1 & 51.000 & Bocor & . & . & 1 & 6 \\
\hline & 2 & 51.000 & Bocor & . & . & 2 & 5 \\
\hline & 3 & 51.000 & Bocor & 0.571 & 0.187 & 3 & 4 \\
\hline & 4 & 67.000 & Bocor & . & . & 4 & 3 \\
\hline & 5 & 67.000 & Bocor & 0.286 & 0.171 & 5 & 2 \\
\hline & 6 & $67.00+$ & $\begin{array}{l}\text { Tidak } \\
\text { Bocor }\end{array}$ & $\cdot$ & & 5 & 1 \\
\hline & 7 & $67.00+$ & Bocor & . & . & 5 & 0 \\
\hline \multirow{7}{*}{$\begin{array}{l}\text { Warm Vertical } \\
\text { Condensation- } \\
\text { AH Plus }\end{array}$} & 1 & 35.000 & Bocor & . & . & 1 & 6 \\
\hline & 2 & 35.000 & Bocor & 0.714 & 0.171 & 2 & 5 \\
\hline & 3 & 51.000 & Bocor & . & . & 3 & 4 \\
\hline & 4 & 51.000 & Bocor & 0.429 & 0.187 & 4 & 3 \\
\hline & 5 & 57.000 & Bocor & . & . & 5 & 2 \\
\hline & 6 & 57.000 & Bocor & 0.143 & 0.132 & 6 & 1 \\
\hline & 7 & $67.00+$ & $\begin{array}{l}\text { Tidak } \\
\text { Bocor }\end{array}$ & . & . & 6 & 0 \\
\hline \multirow{7}{*}{$\begin{array}{l}\text { Warm Vertical } \\
\text { Condensation- } \\
\text { RealSeal }\end{array}$} & 1 & 57.000 & Bocor & 0.857 & 0.132 & 1 & 6 \\
\hline & 2 & 60.000 & Bocor & . & . & 2 & 5 \\
\hline & 3 & 60.000 & Bocor & 0.571 & 0.187 & 3 & 4 \\
\hline & 4 & 64.000 & Bocor & 0.429 & 0.187 & 4 & 3 \\
\hline & 5 & 67.000 & Bocor & 0.286 & 0.171 & 5 & 2 \\
\hline & 6 & $67.00+$ & $\begin{array}{l}\text { Tidak } \\
\text { Bocor }\end{array}$ & · & $\cdot$ & 5 & 1 \\
\hline & 7 & $67.00+$ & $\begin{array}{l}\text { Tidak } \\
\text { Bocor }\end{array}$ & $\cdot$ & $\cdot$ & 5 & 0 \\
\hline
\end{tabular}




\section{PEMBAHASAN}

Penelitian mengenai kebocoran mikro yang berhubungan dengan pengisian saluran akar telah dipelajari secara luas dengan berbagai macam teknik yang berbeda seperti menentukan kebocoran dengan menggunakan penetrasi pewarna, radioisotop, fluid filtration dan penetrasi bakteri. ${ }^{12}$ Dengan banyaknya teknik yang ada untuk mengevaluasi kebocoran endodontik, setiap teknik sering menghasilkan hasil yang bertentangan. Siqueira dkk. ${ }^{13}$ menyatakan bahwa untuk studi kebocoran menggunakan pewarna atau penetrasi isotop, ukuran molekul pewarna atau ion radioaktif menjadi jauh lebih kecil dari bakteri, sehingga membuat hasil klinis tidak signifikan. Saat ini, studi kebocoran menggunakan kultur bakteri dianggap lebih dapat diandalkan dan relevan secara klinis. Oleh karena itu, dalam penelitian ini dalam mengukur kebocoran saluran akar menggunakan penetrasi bakteri.

Pada penelitian ini, penetrasi bakteri yang digunakan adalah bakteri $E$. faecalis. Portenier dkk. ${ }^{14}$ melaporkan bahwa bakteri E. faecalis merupakan spesies yang paling umum terdapat pada perawatan saluran akar yang gagal dan bakteri yang sangat persisten karena kemampuannya dalam bertahan dalam kondisi lingkungan yang basa, tumbuh dalam konsentrasi garam yang tinggi, rentang temperatur yang luas dan dapat bertahan hidup walaupun dalam keadaan kekurangan nutrisi. ${ }^{15}$

Penggunaan larutan irigasi pada penelitian ini adalah sodium hipoklorit $(\mathrm{NaOCl}) 2.5 \%$, EDTA (Ethylene Diamine Tetraacetic Acid) $17 \%$, akuades dan klorheksidin glukonat (CHX) 2\%. NaOCl merupakan larutan irigasi yang paling sering digunakan pada perawatan endodontik dan dipercaya sangat efisien dalam melarutkan jaringan organik serta menghilangkan mikroorganisme. Namun, $\mathrm{NaOCl}$ akan bersifat sitotoksik ketika berkontak dengan jaringan periapikal dan larutan ini tidak dapat menghilangkan smear layer yang sangat rentan terhadap penetrasi bakteri. Smear layer yang terdiri dari sisa-sisa jaringan pulpa, bakteri, dan sisa-sisa dentin akibat preparasi dinding saluran akar dapat masuk ke dalam tubulus dentin dan dapat dihilangkan dengan menggunakan larutan EDTA $17 \% .{ }^{16}$ Larutan irigasi CHX glukonat, di sisi lain, dapat membunuh sel E. faecalis dalam waktu 30 detik dengan konsentrasi 0,2-2\%. ${ }^{17}$

Penelitian ini membandingkan pengaruh dua teknik pengisian saluran akar menggunakan siler berbahan dasar resin terhadap penetrasi bakteri E. faecalis. Teknik pengisian saluran akar yang digunakan yaitu teknik warm vertical condensation dan teknik single cone dengan siler yang digunakan adalah siler RealSeal dengan kombinasi Resilon dan siler AH Plus dengan kombinasi guta perca konvensional. Subjek pada penelitian ini minimal $(\mathrm{n})=7$. Subjek penelitian dibagi menjadi 4 kelompok secara acak. Masing-masing kelompok terdiri dari 7 sampel. Setiap kelompok memiliki 1 sampel sebagai kontrol. Sampel yang digunakan dalam penelitian ini adalah gigi premolar bawah karena gigi premolar bawah 90\% memiliki akar tunggal dan lurus.

Perbedaan kebocoran bakteri antar kelompok eksperimen disebabkan oleh beberapa faktor, antara lain variasi ketebalan siler pada saat pengisian saluran akar, masih terdapatnya smear layer di dalam saluran akar, penyusutan polimerisasi yang terjadi akibat C-faktor dalam saluran akar, faktor kelarutan siler dan jenis siler itu sendiri. ${ }^{18}$

Hasil penelitian ini dengan uji statistik KruskalWallis menunjukkan bahwa sampel gigi yang diobturasi dengan siler RealSeal dan siler AH Plus baik dengan teknik pengisian warm vertical condensation dan teknik single cone tidak memiliki kebocoran mikro secara signifikan antar kelompok, akan tetapi pada uji statistik Kaplan-Meier tetap ada perbedaan dalam hal survival time, Kelompok 4 (Warm Vertical Condensation RealSeal) memiliki tingkat kebocoran yang paling rendah diantara kelompok yang lain, terlihat dari hasil penelitian, kebocoran mulai terjadi pada hari ke-57. Sedangkan kebocoran tercepat terjadi pada kelompok 1 (Single Cone - AH Plus), mulai terjadi pada hari ke-35.

Pada kelompok 1 (Single Cone - AH Plus), penetrasi bakteri terjadi pada hari ke-35 memiliki persentase kebocoran 71,4\% (Gambar 3). Urutan larutan irigasi yang digunakan sangat menentukan kebocoran yang terjadi, apabila larutan irigasi $\mathrm{NaOCl}$ digunakan sebagai larutan irigasi terakhir dapat meningkatkan kebocoran karena larutan $\mathrm{NaOCl}$ merupakan agen oksidasi yang kuat yang dapat mengurangi kekuatan ikat dengan menghambat polimerisasi resin. Irigasi larutan $\mathrm{NaOCl}$ sebaiknya dilakukan terlebih dahulu diikuti dengan EDTA 17\%, setelah itu dengan akuades untuk mengurangi efek $\mathrm{NaOCl}$ pada polimerisasi siler resin ${ }^{19}$ dan larutan irigasi klorheksidin $2 \%$ sebaiknya digunakan sebagai larutan irigasi terakhir karena klorheksidin dapat menghambat akumulasi lebih lanjut dari pembentukan biofilm dari jamur dan mikroorganisme lainnya. ${ }^{20}$

Pada kelompok 2 (Single Cone - RealSeal), penetrasi bakteri yang terjadi pada hari ke-51 memiliki persentase kebocoran 57,1\% (Gambar 4). Kebocoran ini disebabkan karena ketebalan dari siler yang dihasilkan oleh teknik single cone, semakin tebal siler semakin tinggi penyusutan pada saat polimerisasi. C-faktor yang sangat tinggi juga berpengaruhi terhadap kebocoran yang terdapat di dalam saluran akar, ${ }^{21}$ primer yang terkandung dalam siler RealSeal tidak selalu cukup untuk membentuk sistem monoblok dalam saluran akar. ${ }^{22}$ Pada penelitian ini, larutan irigasi EDTA 17\% digunakan untuk menghilangkan smear layer. Adanya smear 
layer terhadap dentin membuat ikatan yang terjadi menjadi lemah dan tidak dapat menahan penyusutan pada saat proses pengerasan. Resin yang terdapat pada siler akan menarik smear layer dari dentin dan memberikan jalan untuk kebocoran mikro. ${ }^{23}$

Pada kelompok 3 (Warm Vertical Condensation AH Plus), penetrasi bakteri yang terjadi pada hari ke-35 memiliki persentase kebocoran 71,4\% (Gambar 5). Dari hasil penelitian ini didapatkan bahwa kebocoran yang terjadi pada pengisian saluran akar menggunakan warm vertical condensation lebih baik dari teknik single cone. Dengan teknik warm vertical condensation, ketebalan siler akan terbentuk tipis di sepanjang sepertiga tengah dan koronal saluran akar apabila dibandingkan dengan teknik single cone. Dalam teknik single cone, adanya master poin yang memiliki kekerucutan lebih besar yang sesuai dengan geometri nikel-titanium rotary instrument menyebabkan siler akan lebih banyak terjadi pada saluran akar. $^{24}$

Pada kelompok 4 (Warm Vertical Condensation RealSeal), penetrasi bakteri yang terjadi pada hari ke-57 memiliki persentase kebocoran 85,7\% (Gambar 6). Penelitian yang dilakukan Paque dan Sirtes, ${ }^{25}$ kebocoran kelompok siler RealSeal dengan teknik warm vertical condensation terjadi setelah hari ke-90. Berdasarkan penelitian De Munck dkk., ${ }^{26}$ setelah 90 hari, semua perlekatan dentin menunjukkan penurunan secara mekanis dan morfologi. Ikatan yang berkurang menjadi penyebab meningkatnya kebocoran. Faktor lain yang menyebabkan meningkatnya kebocoran jangka panjang adalah penyerapan air dan kelarutan dari siler tersebut. Pada saat irigasi dalam perawatan saluran akar, tetesan larutan irigasi akan tersimpan dalam tubuli dentin dan tidak dapat kering walaupun menggunakan paper point. Siler RealSeal bersifat hidrofilik dan mengandung ionik monomer, hal ini yang menyebabkan rentan terkena penyerapan air dan hidrolisis. Penelitian Donnelly dkk. ${ }^{27}$ menemukan bahwa siler RealSeal dibandingkan dengan siler AH Plus memiliki penyerapan air yang lebih besar yaitu $8,02 \%$ dan $1,07 \%$ dan daya larut siler RealSeal lebih besar yaitu 4,02\% dibandingkan dengan siler $\mathrm{AH}$ Plus yaitu $0,16 \%$.

Kombinasi siler RealSeal dengan Resilon memiliki tingkat kebocoran yang lebih rendah dibandingkan dengan siler AH Plus dengan guta perca, hal ini disebabkan dari bahan masing masing siler dan guta perca tersebut, Resilon merupakan bahan termoplastik yang terdiri dari biodegradable synthetic polyester yang dinamakan polycaproplactone, bahan ini mengandung partikel filler yang terbuat dari bioactive glass, bismuth oxychloride dan barium sulfate. ${ }^{18}$ Resilon digunakan bersama dengan siler RealSeal yang memiliki sistem dual-cured dan self-etching primer dan membentuk ikatan monoblok dimana Resilon secara kimiawi akan melekat dengan siler RealSeal, dan siler RealSeal akan melekat dengan dentin. ${ }^{4}$ Pada pemakaian siler AH Plus yang diulasi pada guta perca biasa, guta perca biasa tidak bisa melekat ke dalam struktur internal gigi yang menyebabkan perlekatan terhadap dinding saluran akar lebih rendah. Hal inilah yang menyebabkan kebocoran bakteri lebih terjadi pada kombinasi siler AH Plus dengan guta perca dibandingkan dengan kombinasi siler RealSeal dengan Resilon. ${ }^{28}$

Hasil pada penelitian ini menunjukkan bahwa teknik single cone dalam pengisian saluran akar tidak dapat menjamin penutupan apikal yang baik dan tahan lama terhadap kebocoran bakteri bila dibandingkan dengan teknik warm vertical condensation. Dengan demikian, efektivitas teknik single cone dalam perawatan endodontik harus dievaluasi lebih lanjut dalam uji klinis acak. $^{24}$

\section{KESIMPULAN}

Berdasarkan hasil penelitian mengenai perbedaan pengaruh dua teknik pengisian saluran akar menggunakan siler berbahan dasar resin terhadap penetrasi E. faecalis dapat disimpulkan bahwa tidak ada perbedaan kebocoran mikro yang terjadi antar kelompok sehingga pada penelitian ini hipotesis yang dianjurkan di awal tidak terbukti. Perbedaan yang terjadi antar kelompok hanya dari segi survival time yang disebabkan oleh beberapa faktor antara lain variasi ketebalan siler pada saat pengisian saluran akar, terdapatnya smear layer di dalam saluran akar, penyusutan polimerisasi yang terjadi akibat C-faktor dalam saluran akar, faktor kelarutan dan jenis siler itu sendiri.

Sebaiknya dilakukan penelitian lebih lanjut dengan bahan dan teknik pengisian yang sama tetapi dengan metode selain penetrasi bakteri, sehingga bisa didapatkan hasil lain sebagai perbandingan kebocoran pengisian saluran akar menggunakan penetrasi bakteri dengan metode lain guna mencari kebocoran minimal dalam pengisian saluran akar.

\section{KONFLIK KEPENTINGAN}

Tidak ada konflik kepentingan dalam penelitian ini.

\section{DAFTAR PUSTAKA}

1. Roda RS, Getleman BH. Non surgical Retreatment. Dalam Pathway of the Pulp. Cohen S, Hargreaves KM (editor). Ed Ke-9.St.Louis; Mosby; 2006. Hlm. 944-1010.

2. Khedmat S, Aligholi M,Jafari M. Combined bacterial-fungal penetration after obturation with ah 26 and ah plus root canal sealers. J Dent. 2009; 6(4):187-92. 
3. Soedjono P, Mooduto L,Setyowati, L. Penutupan apeks pada pengisian saluran akar dengan bahan kalsium oksida lebih baik dibanding dengan kalsium herokside. Jurnal Persatuan Dokter Gigi Indonesia. 2009;58:1-5.

4. Oddoni PG, Mello I, Coil JM, Antoniazzi JH Coronal and apical leakage analysis of two different root canal obturation systems. Brazil Oral Res. 2008; 22(3):211-5.

5. Pameijer CH, Zmener O. 2010. Resin Materials for root canal obturation. Dent Clin North Am. 2010;54:325-44.

6. Uppal M, Kaur, G. Comparative evaluation of sealing ability of the lateral condensation and the protaper single cone obturation technique after canal preparation by the Protaper Niti Rotary System - An In Vitro Study. J Indian Dent Assoc. 2011; 5(3):33840.

7. Venturi M. Evaluation of canal filling after using two warm vertical gutta-percha compaction techniques in vivo: a preliminary study. Int Endodon J. 2006; 39(7):538-46.

8. Aminsobhani M, Ghorbanzadeh A, Bolhari B, Shokouhinejad N, Ghabraei S, Assadian H, Aligholi M. Coronal microleakage in root canals obturated with lateral compaction, warm vertical compaction and GuttaFlow system. Iran Endod J. 2010;5(2):837.

9. Ishimura H, Yoshioka T, Suda H. Sealing ability of new adhesive root canal filling materials measured by new dye penetration method. Dent Mater J. 2007; 26(2):290-6.

10. Torabinejad M, Ung B, dan Kettering JD. In vitro bacterial penetration of coronally unsealed endodontically treated teeth. J Endod. 1990;16(12):566-9.

11. Sing H. Microbiology ofendodontic infections. J Dent Oral Health. 2016;4(2):1-4.

12. Verissimo DN, Vale MS. Methodologies for assessment of apical and coronal leakage of endodontic filling materials : a critical review. J Oral Sci. 2006; 48(3):93-8.

13. Siqueira JF, Rocas IN, Abad EC, Castro AJ, Gahyva SM,Favieri A. Ability of three root-end filling materials to prevent bacterial leakage. J Endod. 2001; 27(11):673-5.

14. Portenier I, Waltimo T, Haapasalo M. Enterococcus faecalis-the root canal survivor and star in post treatment disease. Endod Topics. 2003;6:135-59.

15. Mathew, S. dan Boopathy T.. Enterococcus faecalis - An endodontic challenge. J Ind Aca Dent Spec. 2010. 1(4):46-8.

16. Gomes NV, Ferraz CCR, Gomes BPFA, Zaia AA,
Teixeira FB, Souza-Filho FJ. Influence of irrigants on the coronal microleakage of laterally condensed gutta-percha root fillings. Int Endodon $\mathrm{J}$. 2002;35(9):791-5.

17. Haapasalo M, Endal U, Zandi, H, Coil JM. Eradication of endodontic infection by instrumentation and irrigation solutions. Endod Topics. 2005;10:77-102.

18. Ko CH, Pan GS, Cheung, Chan AW. A review of a resin based root canal filling material. Hong Kong Dent J. 2008;5(1):38-44.

19. Eldeniz AU, Ørstavik D. A laboratory assessment of coronal bacterial leakage in root canals filled with new and conventional sealers. Int Endodon J. 2009; 42(4):303-12.

20. Mohammadi Z, Abbott PV. The properties and applications of chlorhexidine in endodontics. Int Endodon J. 2009;42(4):288-302.

21. Tay FR, Loushine RJ, Lambrechts P, Weller RN, Pashley DH. Geometric factors affecting dentin bonding in root canals: a theoretical modeling approach. J Endod. 2005;31(8):584-9.

22. Skidmore LJ, Berzins DW, Bahcall JK. An in vitro comparison of the intraradicular dentin bond strength of resilon and gutta-percha. $J$ Endod. 2006;32(10):963-6.

23. Shipper G, Ørstavik D, Teixeira FB, Trope M. An evaluation of microbial leakage in roots filled with a thermoplastic synthetic polymer-based root canal filling material (resilon). J Endod. 2004;30(5):342-7.

24. Monticelli F, Sadek, FT, Schuster GS, Volkmann KR, Looney SW, Ferrari M, Toledano M, Pashley DH, dan Tay FR. Efficacy of two contemporary single-cone filling techniques in preventing bacterial leakage. J Endod. 2007;33(3):310-3.

25. Paque, F. dan Sirtes, G. Apical sealing ability of Resilon/Epiphany versus gutta-percha/AH Plus: immediate and 16-months leakage. Int Endodon J. 2007;40(9):722-9.

26. De Munck, J., Van L.K., Peumans, M., Poitevin, A., Lambrechts, P., Braem, M., dan Van, M.B. A critical review of the durability of adhesion to tooth tissue: methods and results. J Dent Res. 2005;84(2):118-32.

27. Donnelly, A., Sword, J., Nishitani, Y., Yoshiyama, M., Agee, K., Tay, F.R., dan Pashley, D.H. Water sorption and solubility of methacrylate resin-based root canal sealers. J Endod. 2007;33(8):990-4.

28. Aptekar, A. dan Ginnan, K. Comparative analysis of microleakage and seal for 2 obturation materials: resilon/epiphany and gutta-percha. J Can Dent Assoc. 2006;72(3):245-245d. 